\title{
Sulfated Polysaccharides as Specific Biologically Active Materials
}

\author{
特異な生理活性を持つ硫酸化糖鎖マテリアル \\ Muschin, Tegshi ${ }^{1}$; Han, Shuqin ${ }^{1,2}$; Ishimura, Hisataka ${ }^{1}$; and Yoshida, Takashi ${ }^{1}$ \\ ${ }^{1}$ Department of Bio and Environmental Chemistry, Faculty of Engineering, \\ Kitami Institute of Technology, Koen-cho 165, Kitami 090-8507, Hokkaido, Japan \\ ${ }^{2}$ College of Chemistry and Chemical Engineering, Inner Mongolia University, Hohhot, 010021, P. R. China \\ FAX: 81-157-26-9388, E-mail: yoshida@chem.kitami-it.ac.jp
}

(Received on November 21, 2011, accepted on December 5, 2011)

Key Words: sulfated polysaccharide, anti-viral activity, polysaccharide-protein interactions, NMR, SPR

\begin{abstract}
Sulfated polysaccharides are related to recognition and many biological activities in an organism. The action mechanism has become apparent by means of nuclear magnetic resonance (NMR) and surface plasmon resonance (SPR) apparatus. In this minireview, we describe the recent synthesis, biological activity, and relationship between structure and biological activity of polysaccharides.
\end{abstract}

\section{A. Introduction}

Sulfated polysaccharides are known to have unique biological activities including antiviral and blood anticoagulant activities. In particular, curdlan sulfate, which is prepared by sulfation of a natural polysaccharide, curdlan, had potent anti-HIV activity at a concentration as low as $3.3 \mu \mathrm{g} / \mathrm{ml}$ (1), and heparin is the strongest known blood anticoagulant natural polysaccharide (2). The elucidation of carbohydrateprotein interactions is important not only to understand the antiviral mechanism of sulfated polysaccharides, but also to develop new and effective medicines or biomaterials. For this purpose, synthesis of polysaccharides with defined structures is necessary. Ring-opening polymerization of anhydro sugar derivatives is an excellent method to synthesize of stereoregular polysaccharides with defined structures and high molecular weights. Since the first paper on the synthesis of stereoregular polysaccharide by the ring-opening polymerization of anhydro sugar derivatives (3), many anhydro sugar monomers have been synthesized and their ring-opening polymerizations were examined by Schuerch $(4,5)$, Okada $(6)$, Uryu $(7,8)$. To date, we have investigated the synthesis of stereoregular polysaccharides by the ring-opening polymerization of anhydro sugar derivatives and subsequent deprotection. We have also synthesized sulfated polysaccharides by sulfation of naturally occurring polysaccharides (9). Studies using both synthetic and naturally occurring polysaccharides are important ways
要 約

硫酸化糖鎖は生体内での認識や多くの生理活性に関わっ ている。その作用メカニズムは核磁気共鳴装置（NMR）や表 面プラズモン共鳴装置（SPR）などによって明らかになりつつ ある。このミニレビューでは糖鎖に関する最近の合成、生理 活性、構造と生理活性との関係などについて述べる。

A. はじめに

硫酸化糖鎖は抗ウイルス性や抗凝血作用など特異な生理 活性を持つことが知られている。特に天然の糖鎖カードラン を硫酸化して合成したカードランは、3.3 $\mathrm{\mu g} / \mathrm{ml}$ という低濃度 で高い抗 HIV 作用を持つことが分かり (1)、へパリンは最も高 い抗凝血作用を持つ天然の硫酸化糖鎖として知られている $(2)$ 。 糖鎖とタンパク質間の相互作用の解明は硫酸化糖鎖の抗ウイ ルス性メカニズムの理解だけでなく新しく効果的な薬やバイ オマテリアルの開発にとっても重要である。この目的のため に明確な構造を持つ糖鎖の合成は必要である。無水糖モノマー の開環重合法による立体規則性糖鎖の合成は高分子量で構造 明確な糖鎖をえることができるたいへんよい方法である。開 環重合法による立体規則性糖鎖の初めての報告 (3) 以来、多く の無水糖モノマーが合成され、それらの開環重合はシャーシ $(4$, 5)、岡田 (6)、瓜生 $(7 、 8)$ らによって成し遂げられてきた。我々 も無水二糖モノマーや無水三糖モノマーを含む多くの無水糖 モノマーを合成し糖鎖構造と生理活性との関係について研究 してきた (9)。構造明確な合成糖鎖と天然糖鎖の両方を用いる 研究は糖鎖の構造と生理活性との関係を知るために重要な方 
to investigate the structure-biological activity relationships of polysaccharides. Nuclear magnetic resonance (NMR) and surface plasmon resonance (SPR) are good tools for studying interactions between polysaccharides and proteins. In this minireview, we focus the results since around the year 2000 of studies on the ring-opening polymerization of anhydro sugar monomers into stereoregular polysaccharides and on the antiviral activities of sulfated synthetic and natural polysaccharides.

\section{B. Synthesis of Stereoregular Polysaccharides \\ B-1. Ring-Opening Polymerization of Anhydro Sugar Derivatives}

The ring-opening polymerization of anhydro sugar derivatives into stereoregular polysaccharides was first reported by Schuerch in 1966, who prepared benzylated 1, 6anhydro- $\beta$-D-glucopyranose (LGTBE) $\mathbf{1}$ and polymerized it using phosphorus pentafluoride (PF5) as a cationic catalyst under high vacuum to give $(1 \rightarrow 6)$ - $\alpha$-D- glucopyranan 3 after reductive deprotection of benzyl groups to recover hydroxyl groups by sodium in liquid ammonia, as shown in Scheme 1 (3). The yield and molecular weight of polymers produced by
法論となる。核磁気共鳴 (NMR) や表面プラズモン共鳴 (SPR) はそれを成し遂げるためのたいへん有効なツールとなる。こ のミニレビューでは主に 2000 年以降の研究に焦点を絞り無水 糖モノマーの開環重合法により合成した立体規則性硫酸化糖 鎖と天然の硫酸化糖鎖の抗ウイルス性などの生理活性につい て述べる。

\section{B . 立体規則性糖鎖の合成}

B-1 無水糖モノマーの開環重合

無水糖モノマーの開環重合法による立体規則性糖鎖の合 成は 1966 年にシャーシによって初めて報告された。シャー シはベンジル化 1,6-無水グルコース（LGTBE）1 を合成し、 PF5 触媒、高真空下による開環重合を行い、液体アンモニア 中金属ナトリウムを用いるバーチ還元によってベンジル基の 脱保護を行いScheme 1 に示すように $(1 \rightarrow 6)-\alpha-D-$ グルコピラナ ン 3 を得た (3)(スキーム 1$)$ 。得られた合成糖鎖の収率や分子 量は高いものであった。ベンジル基は水酸基のたいへんよい

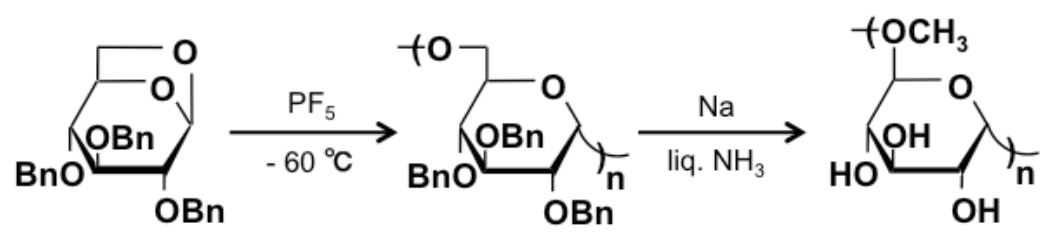

1

2

3

Scheme 1. Ring-opening polymerization of benzylated 1,6-anhydroglucose 1 into stereoregular $(1 \rightarrow 6)$ - $\alpha$-D-glucopyranan (dextran).

the ring-opening polymerization were high. The benzyl group is a good protection group for a hydroxyl group because it is easily deprotected to recover the hydroxyl group in high yield.

Most monosaccharides have eight aldohexoses with six carbons and four aldopentoses with five carbons. In those monosaccharides, five and four anhydro hexose and pentose monomers have been synthesized and polymerized to give the corresponding 1, 6- $\alpha$-D-hexopyranan and 1, 5- $\alpha$-Dpentofuranans after deprotection to recover hydroxyl groups. For example, 1, 4-anhydro-2,3-di- $O$-benzyl- $\alpha$-D-ribopyranose 4 in $\mathrm{CH} 2 \mathrm{Cl} 2$ at $-40^{\circ} \mathrm{C}$ with $\mathrm{BF}_{3} \mathrm{OEt}_{2}$ as the catalyst gave a new polysaccharide, 1,5- $\alpha$-D-ribofuranan 5, after deprotection (10). On the other hand, the highly stereoregular 2,3-O-benzylidene$(1 \rightarrow 4)$ - $\beta$-D-ribopyranan was synthesized by selective ringopening polymerization of a pentose monomer, 1,4- anhydro2,3-O-benzylidene- $\alpha$-D-ribopyranose 6 at $-40{ }^{\circ} \mathrm{C}$ with $\mathrm{SbCl}_{5}$ as the catalyst in $\mathrm{CH}_{2} \mathrm{Cl}_{2}$ and then deprotected to give $(1 \rightarrow$
保護基であり簡単の脱保護を行うことができて水酸基を再生 することができる。

ほとんどの単糖類は 8 種類の 6 個の炭素から成るアルド ヘキソースと 4 種類の 5 個の炭素から成るアルドペントース に分類される。これらの単糖類のうち、5つの無水へキソー スモノマーと 4 つの無水ペントースモノマーが合成され、開 環重合によって 6 員環構造の立体規則性糖鎖である $1,6-\alpha-\mathrm{D}-$ ヘキソピラナン、 5 員環構造を持つ立体規則性糖鎖の 1, 5- $\alpha$-Dペントフラナンが得られた。たとえば、無水リボースのモノ マーである 1, 4- アンヒドロ -2,3- ジ -O-ベンジル - $\alpha$-D- リボピラ ノース 4 は塩化メチレン溶媒、 $-40^{\circ} \mathrm{C}$ で $\mathrm{BF}_{3}$ エーテラート触媒 により重合し新しい立体規則性糖鎖である 1,5- $\alpha$-D- リボフラナ ン 5 が得られた $(10)$ 。一方、高い立体規則性を持つ 2,3-O-ベン ジリデン - ( $1 \rightarrow 4)-\beta$-D- リボピラナンは 1,4 - アンヒドロ -2,3-O-ベ ンジリデン $-\alpha$-D-リボピラノース 6 モノマーの - 40 ํㅡ、五塩化 アンチモン $\left(\mathrm{SbCl}_{5}\right)$ 触媒による開環重合し脱保護によって 6 
4)- $\beta$-D-ribopyranan 7 consisting of a six-membered ring with high molecular weights $([\eta]=0.131 \sim 0.347)(11)$.
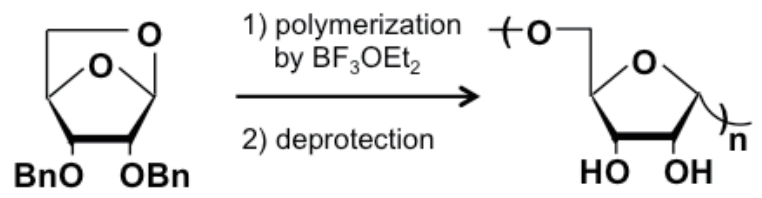

4

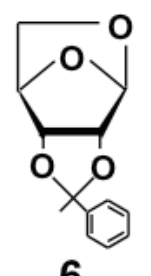

6

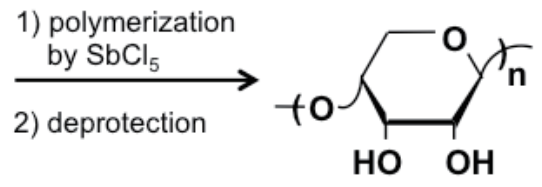

7
員環を持つ $(1 \rightarrow 4)-\beta$-D- リボピラナン 7 が得られた $(11)$ 。このと きの粘度は $([\eta]=0.131 \sim 0.347)$ であり高い分子量を持つこと が分かった。

Scheme 2. Selective ring-opening polymerization of 1,4-anhydroribose monomers.
Recently, we prepared a new monomer, 1,6-anhydro2,3,4-tri-O-benzyl- $\beta$-D- talopyranose 8 (benzylated 1 , 6 -anhydro- $\beta$-D-talopyranose), which is the sixth anhydro hexose monomer synthesized to date, from D-galactose as a starting monosaccharide by 11 steps and then polymerized it with $\mathrm{PF}_{5}$ as catalyst at low temperature at $-60^{\circ} \mathrm{C}$ under high vacuum to give the corresponding $(1 \rightarrow 6)-\alpha-D-$ talopyranan 9 with around $20 \%$ yields (Scheme 3 ) (12). The copolymerizability with LGTBE 1 was also low.
最近我々は 8 種類のヘキソースからのモノマーのうち第 6 番目に当たる、最も新しい無水糖モノマーの1,6-アンヒド ロ -2,3,4-トリ-O-ベンジル - $\beta$-D- タロピラノース $\mathbf{8}$ (ベンジル化 1 , 6- アンヒドロ - $\beta$-D- タロピラノース) を D- ガラクトースを出発 単糖類として 11 段階で合成した。そして五フッ化リン $\left(\mathrm{PF}_{5}\right)$ 触媒、高真空下、-60 ${ }^{\circ} \mathrm{C}$ で重合させたところ、対応する立体規 則性の 2,3,4-トリ-O-ベンジル - $(1 \rightarrow 6)-\alpha$-D- タロピラナン 9 が 20\%の収率で得られることを見出した ( スキーム 3) (12)。

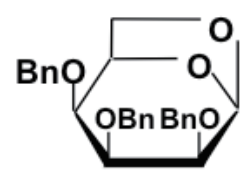

8

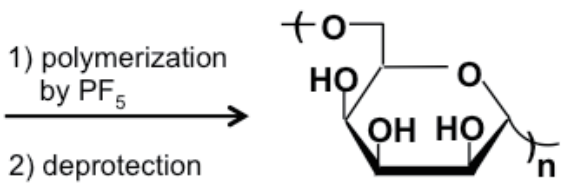

9

\section{Scheme 3. Ring-opening polymerization of benzylated}

1,6-anhydro- $\beta$-D-talopyranose.

The polymerizability of the benzylated 1, 6-anhydro$\beta$-D-talopyranose $\mathbf{8}$ was reported in the order mannose $>$ glucose $>$ galactose $>$ allose $>$ talose $>$ altorose. The order of the polymerizability was determined by the results of copolymerization with the 1,6-anhydro glucose monomer $\mathbf{1}$.

In general, ring-opening polymerization is performed with cationic catalysts under high vacuum conditions at low temperatures because catalysts are unstable at high temperatures and it is necessary to avoid contamination by oxygen and humidity. However, we found that the methylated monomer 1,6-anhydro-2,3,4-tri- $O$-methyl- $\beta$-D-glucopyranose (LGTME) $\mathbf{1 0}$ has high ring-opening polymerizability and
ベンジル化無水グルコースモノマーの LGTBE 1 との共重 合性も低く、1 との共重合比から無水タロースモノマー 8 の重 合性はマンノース > グルコース > ガラクトース > アロース > タロース>アルトロースの順になることが分かった。

一般に、無水糖モノマーの開環重合はカチオン触媒を用い 高真空下低温で行われる。それは触媒が高温になると不安定 になることと酸素や水分の影響を防ぐためである。ところが、 我々はメチル化した無水グルコースモノマーである 1,6- アン ヒドロ - 2,3,4-トリ-O-メチル - $\beta$-D- グルコピラノース (LGTME) 10 は高い開環重合性を持ち、温和な重合条件で容易に重合す ることを見出した(13)。すなわち、三フッ化ホウ素エーテル 
polymerizes under mild conditions (13). With $\mathrm{BF}_{3} \mathrm{OEt}_{2}$ as a catalyst under a normal pressure and $\mathrm{N}_{2}$ atmosphere at $0^{\circ} \mathrm{C}$, the methylated monomer $\mathbf{1 0}$ gave a high molecular weight polymer having two molecular weight fractions, $\overline{\mathrm{M}}_{\mathrm{n}}=161$ $\times 10^{3} \sim 364 \times 10^{3}$ and $\overline{\mathrm{M}}_{\mathrm{n}}=394 \times 10^{3} \sim 2,820 \times 10^{3}$ in the proportion of $4.5: 1$, with complete $1,6-\alpha$ stereoregularity in a high yield (Scheme 4), even though benzylated 1, 6-anhydro glucose monomer $\mathbf{1}$ gave no polymersin the same
$\left(\mathrm{BF}_{3} \mathrm{OEt}_{2}\right)$ 触媒を用いてチッ素気流下、常圧、 $0^{\circ} \mathrm{C}$ の条件で重 合させたところ、4.5:1の割合で 2 つの高分子量成分， $\overline{\mathbf{M}}_{\mathrm{n}}=$ $161 \times 10^{3} \sim 364 \times 10^{3}$ と $\overline{\mathrm{M}}_{\mathrm{n}}=394 \times 10^{3} \sim 2,820 \times 10^{3}$ を 持ち、完全にポリマーが好収率で 1,6- $\alpha$ - 立体規則性のポリマー を与えることを見出した(スキーム 4)。ベンジル化無水グル コースモノマー1 1 同条件での重合ではポリマーを得ること

Scheme 4. Two-step ring-opening polymerization of methylated 1,6-anhydroglucopyranose monomer 10 , which monomer had high ring-opening polymerizability and stable propagating end.
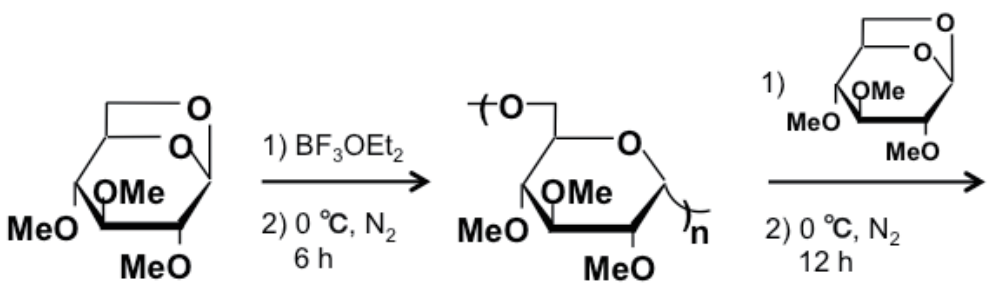

10


polymerization conditions. In addition, we found that this methylated monomer had "living" polymerizability. After the first stage of polymerization under normal pressure for $6 \mathrm{~h}$ at $0{ }^{\circ} \mathrm{C}$, the second methylated monomer was added to the polymerization mixture and then the polymerization was continued for a further $12 \mathrm{~h}$. We found that the lower molecular weight of the resulting polymer was increased to $\overline{\mathbf{M}}_{n}=394 \times$ $10^{3}$ and the yield was $78 \%$. These results suggest that after the first-stage polymerization the polymer has a stable propagating end that has a potential ability to re-starting for the ringopening polymerization.

In our previous reports, three pentose monomers (Fig.1), 1,4-anhydro-2,3-di-O-tert-butyldimethylsilyl- $\alpha$-D-
が出来ないことに比べ $\mathbf{1 0}$ は高い開環重合性を持っていること が分かった。さらにこのメチル化モノマー $\mathbf{1 0}$ はリビング重合 性を示すことも見出した。常圧、 $0^{\circ} \mathrm{C} 、 6$ 時間の第 1 段階目の 重合後にメチル化無水グルコースモノマー 10 を再度加えその まま重合を 12 時間続けた。すると78\%の収率でポリマーが 得られ、分子量は $\overline{\mathrm{M}}_{\mathrm{n}}=394 \times 10^{3}$ まで大きくなることが明ら かとなった。この結果は第 1 段階目の重合において重合終了 後においてもポリマー末端は重合性を保っており再重合性を 持っていることが示唆される結果である。

我々の以前の研究で、3つの無水ペントースモノマー ( 図 1)、1,4-アンヒドロ -2,3- ジ-O-tert-ブチルジメチルシリ

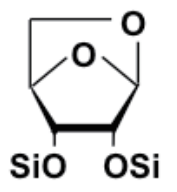

11 ADSR

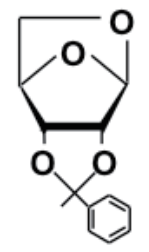

6 ABRP

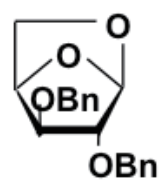

12 ADBX

Fig. 1. 1,4-anhydropentose monomers gave stable propagating end. 
ribopyranose (ADSR) 11, 1,4- anhydro-2,3- $O$-benzylidene- $\alpha$ D-ribopyranose (ABRP) 6, and 1, 4-anhydro-2,3-di-O-benzyl$\alpha$-D-xylopyranose (ADBX) 12, were found to have a stable propagating end (14). That is, these monomers gave the block copolymers consisting of poly(ADSR-ADBR), poly(ABRPADBR), and poly(ADBX-ADBR) having narrow molecular weight dispersion, respectively. In particular, the block copolysaccharide consisting of pyranose and furanose units, $(1 \rightarrow 4)$ - $\beta$-D-ribopyranan and $(1 \rightarrow 5)$ - $\alpha$-D-ribofuranan, was obtained by the first-stage polymerization of ABRP monomer and then by addition of the second ADBR monomer.

\section{B-2. Ring-Opening Mechanism}

For 1,5-anhydro pentose monomers, there are two possible ring-opening mechanisms, oxonium and carbenium ion mechanisms to give 1,5- $\alpha$ linked or mixed structure of 1 , $5-\alpha$ and 1, 5- $\beta$ linked pentofuranans (Scheme 5). For ABRP monomer, the bulky $\mathrm{SbCl}_{5}$ catalyst was complexed to the $\mathrm{C} 1-\mathrm{O}^{+}-\mathrm{C} 4$ oxygen with less steric hindrance, and then ion pairing of $\mathrm{SbCl}_{6}$ - was formed. The next ABRP monomer was attacked from the back side of the complex to give exclusively a 1,4-linked pentopyranan structure. For 1,6-anhydro hexose monomers, ring-opening at a 1,6-linked bond occurred by the complexation of a catalyst at the $\mathrm{C} 1-\mathrm{O}^{+}-\mathrm{C} 6$ oxygen to give 1,6- $\alpha$-linked hexopyranans exclusively $(10,11,15)$.
ル - $\alpha$-D-リボピラノース (ADSR) 11、1,4- アンヒドロ -2,3-O-ベ ンジリデン $-\alpha$ - D- リボピラノース (ABRP) 6、および 1, 4-アン ヒドロ -2,3-ジ-O-ベンジル - $\alpha$-D- キシロピラノース (ADBX) 12 は安定な成長末端を持っていることを示した (14)。すなわち、 これらのモノマーは狭い分子量分布を持つブロック共重合体、 poly(ADSR-ADBR)、poly(ABRP-ADBR)、および poly(ADBXADBR)をそれぞれ与えた。特にブロック共重合体のうち、(1 $\rightarrow 4)-\beta$-D- リボピラナンおよび ( $1 \rightarrow 5)-\alpha$-D - リボフラナンのピラ ノースユニットとフラノースユニットからなる共重合体、す なわち はベンジリデン化無水リボースモノマーABRP 6 を始めに重合させた後にベンジル化無水リボースモノマー ADBR を加えることにより得られることが分かった。

B-2. 開環重合のメカニズム

1,5- 無水ペントースモノマーの場合、Scheme 5 に示すよ うに 2 つの開環重合メカニズム、すなわちオキソニウムおよ びカルベニウムメカニズムによって 1,5- $\alpha$ 結合の立体規則性ポ リマーか 1,5- $\alpha$ と 1,5- $\beta$ 構造の混合構造を持つペントフラナン を与える(スキーム 5)。ABRP モノマー6では大きな五塩化ア ンチモン $\left(\mathrm{SbCl}_{5}\right)$ 触媒がより立体障害の少ない $\mathrm{C} 1-\mathrm{O}^{+}-\mathrm{C} 4$ 酸素 に配位して $\mathrm{SbCl}_{6^{-}}$とのイオンエアーを形成する。そして次の ABRP モノマーが形成した錯体に対し背面攻撃を行い、1,4- $\beta$ 結合を持つ 6 員環構造のペントピラナンポリマーをのみを与 える。また、6 個の炭素を持つ 1,6- 無水へキソースモノマー では触媒が $\mathrm{C} 1-\mathrm{O}^{+}-\mathrm{C} 6$ 酸素に配位して 1,6- 結合が開くことに よって開環重合が起こり、1,6- $\alpha$ 結合を持つ 6 員環構造のへキ ソピラナンポリマーのみを与える $(10 、 11 、 15) 。$

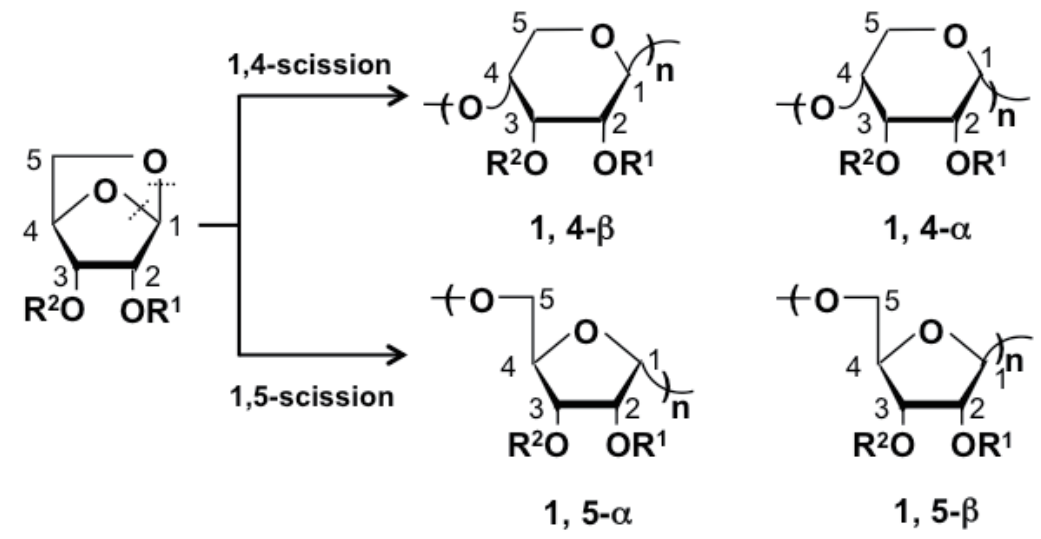

Scheme 5. Ring-opening modes of 1,4-anhydro- $\alpha$-D-ribopyranose monomer.

\section{B-3. Ring-Opening Polymerization of Di and Trisaccharide Monomers into Branched Polysaccharides}

Synthetic polysaccharides have a linear structure. In nature, on the other hand, branched polysaccharides are common structures and are involved in several biological activities such as recognition between cell and cell, viruses, bacteria, and toxins. It is difficult to determine the relationship between the structures of polysaccharides and their biological activities because natural polysaccharides have complex and branched structures. Therefore, branched polysaccharides
B-3. 無水二糖モノマー、無水三糖モノマーの開環重合による 分枝多糖の合成

合成で得られた糖鎖はふつう直鎖状構造である。しかし天 然では分枝構造を持つ糖鎖がふつうであり、その分枝構造が 多くの生理活性に関与していると推定される。すなわち、細 胞と細胞、ウイルス、細菌や毒性物質などとの認識に関わっ ていると思われる。しかし、天然の糖鎖が複雑な分枝構造を もっているため、糖鎖の構造と生理活性との関係を調べるこ とは通常は極めて困難な課題である。それゆえ、合成によっ 
with defined structures obtained by synthesis are expected to be model polysaccharides for biological studies of naturally occurring polysaccharides. In 1970, Schuerch reported two anhydro disaccharide monomers, benzylated 1, 6-anhydro cellobiose and maltose, that were polymerized to give $\beta$ and $\alpha$-glucose a branched $(1 \rightarrow 6)-\alpha$-D-glucopyranans with a comb-shaped structure, respectively $(16,17)$. The proportion of branched glucoses was changed by the copolymerization with benzylated 1,6-anhydro glucopyranose (LGTBE) 1 . In 1993, Kobayashi synthesized 1,6-anhydro mannobiose monomer, 1,6-anhydro-2,3-di-O-benzyl-4-O-(2,3,4,6-tetra$O$-benzyl- $\alpha$-D-mannopyranosyl)- $\beta$-D-mannopyranose, and obtained the corresponding mannose branched polysaccharide, 4-O- $\alpha$-D-mannopyranosyl-( $1 \rightarrow 6)-\alpha$-D-mannopyranan after ring-opening polymerization using $\mathrm{PF}_{5}$ as the catalyst and subsequent debenzylation (18).

We have also reported the synthesis of branched polysaccharides by ring-opening polymerization of a new anhydro disaccharide monomer (19). Lactose is one of the three natural disaccharides, lactose, sucrose, and trehalose. We used lactose to synthesized a 1,6- anhydro disaccharide monomer, 1,6-anhydro-2,3-di- $O$-benzyl-4- $O$ - $\left(2^{\prime}, 3^{\prime}, 4^{\prime}, 6^{\prime}\right.$ tetra- $O$-benzyl- $\beta$-D-galactopyranosyl)- $\beta$-D-glucopyranose (benzylated 1,6-anhydro lactose (LSHBE)) 13, and then revealed the ring-opening polymerizability. The ring-opening polymerization of LSHBE $\mathbf{1 3}$ was carried out using PF5 as a catalyst under high vacuum to give a stereoregular benzylated $(1 \rightarrow 6)-\alpha$-D-lactopyranan 14 . The polymerization temperatures affected both molecular weights and yields of the polymers. At $-60{ }^{\circ} \mathrm{C}$, homopoly(LSHBE) had the highest yield, $68.5 \%$, and at $-78{ }^{\circ} \mathrm{C}$, homopoly(LSHBE) had the highest molecular weight, $\overline{\mathrm{M}}_{\mathrm{n}}=7.3 \times 10^{3}$ (Scheme 6 ). The copolymerizability of LSHBE 13 with LGTBE 1 was high, and the corresponding
て得られた構造明確な分枝多糖類は、モデル化合物として天 然糖鎖の生理活性を調べる研究に期待できる。1970年にシャー シは $2 つ の$ 無水二糖モノマー、すなわち、ベンジル化無水セ ロビオースモノマーとマルトースモノマーを合成し開環重合 させることにより、それぞれ $\beta$-と $\alpha$-グルコース分枝を持つ櫛 型糖鎖の合成に成功した (16、17)。枝の割合は、1,6- 無水グル コースモノマー1 との共重合によって任意に変化させること が出来た。1993年に小林らは無水マンノース二糖モノマー、1,6アンヒドロ -2,3- ジ -O-ベンジル - 4-O-(2,3,4,6-テトラ-O-ベン ジル - $\alpha$-D- マンノピラノシル )- $\beta$-D- マンオピラノースを合成し、 $\mathrm{PF}_{5}$ 触媒を用いる開環重合によって対応するマンノースが1つ 分枝したマンノース主鎖の分枝糖鎖、4-O- $\alpha$-D- マンノピラノシ ル -(1 $1 \rightarrow 6)-\alpha-D-$ マンノピラナンを得ることが出来た (18)。

我々も新しい無水二糖モノマーを合成し開環重合による 分枝多糖類の合成について報告した(19)。すなわち、天然の二 糖類は 3 種類あり、ラクトース、スクロース、トレハロース、 我々はそのうちラクトースから 1,6- 無水二糖モノマーである、 1,6- アンヒドロ -2,3- ジ -O-ベンジル - 4-O-(2',3',4',6'- テトラ - Oベンジル - $\beta$-D- ガラクトピラノシル ) $-\beta$-D- グルコピラノース ( ベ ンジル化 1,6-無水ラクトース (LSHBE)) 13 を合成した。この モノマーは高真空下 PF5 触媒で開環重合し 1,6-グルコピラナ ンの主鎖に 1 つの糖残基当たりガラクトースが 1 つ分枝した ベンジル化 (1 $(16)-\alpha-D-$ ラクトピラナン $\mathbf{1 4}$ を与えた。このモ) マーの重合ではポリマーの分子量や収率に及ぼす重合温度の 影響が大きいことが明らかになった。-60Cで $68.5 \%$ の最も高 い収率で対応するポリマーを与え、 $-78^{\circ} \mathrm{C} て ゙ は$ 最も高い分子量、 $\overline{\mathrm{M}}_{\mathrm{n}}=7.3 \times 10^{3}$ のポリマーを与えた(スキーム 6)。LGTBE $\mathbf{1}$ との共重合性は高く、種々の割合で対応するグルコースとラ



13 LSHBE

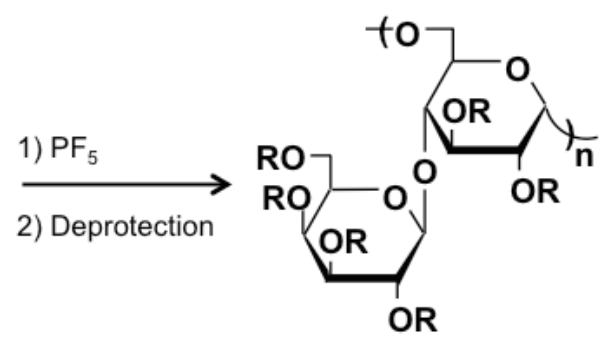

$14 \mathrm{R}=\mathrm{Bn}$

$15 \mathrm{R}=\mathrm{H}$

$16 \mathrm{R}=\mathrm{H}$ or $\mathrm{SO}_{3} \mathrm{Na}$

\section{Scheme 6. Ring-opening polymerization of anhydro disaccharide, LSHBE.}

copolysaccharides with different proportions of lactose and glucose units were obtained in good yields. In addition, the structure-biological activity relationship was also elucidated. We found that sulfated homopoly(lactose)s 16 had moderate anti-HIV $\left(\mathrm{EC}_{50}=5.9\right.$ and $\left.1.3 \mu \mathrm{g} / \mathrm{ml}\right)$ and blood anticoagulant
クトースユニットを持つ分枝糖鎖を好収率で合成することが できた。さらに構造と生理活性との関係を明らかにした。硫 酸化したラクトースのみから成る糖鎖、すなわちすべてのグ ルコース主鎖ユニットにガラクトースの分枝がある構造、で は中間的な抗 HIV 作用、 $\left(\mathrm{EC}_{50}=5.9\right.$ and $\left.1.3 \mu \mathrm{g} / \mathrm{ml}\right)$ 㧍よび抗 
activities ( $\mathrm{AA}=18$ and 13 unit $/ \mathrm{mg}$ ) compared to those of standard dextran $\left(\mathrm{EC}_{50}=0.84 \mu \mathrm{g} / \mathrm{ml}\right.$ and $\left.\mathrm{AA}=22.9 \mathrm{unit} / \mathrm{mg}\right)$ and curdlan sulfates $\left(\mathrm{EC}_{50}=0.13 \mu \mathrm{g} / \mathrm{ml}\right.$ and $\mathrm{AA}=19$ unit $/$ $\mathrm{mg}$ ) in potency of activities. For sulfated poly(lactose-coglucose) 17, the biological activities increased with a decrease in the proportion of lactose units. Sulfated poly(lactose-coglucose) having $15 \mathrm{~mol} \%$ lactose units had high anti-HIV and blood anticoagulant activities of $0.3 \mu \mathrm{g} / \mathrm{ml}$ and $54 \mathrm{unit} / \mathrm{mg}$, respectively. The cytotoxicity $\left(\mathrm{CC}_{50}\right)$ was below $276 \mu \mathrm{g} / \mathrm{ml}$. These biological results suggest that the distance between branched units on the main chain plays an important role in the anti-HIV and blood anticoagulant activities.

Among the anhydro sugar monomers we synthesized, 1,4-anhydro ribose was one of the monomers with high ringopening polymerizability $(10,11)$. Therefore, we selected this monomer for synthesis of the main chain, and galactose and lactose for branched moieties to give new di- and trisaccharide monomers, 1, 4-anhydro-2-O-benzyl-3-O-(2,3,4,6-tetra- $O$ benzyl- $\beta$-D-galactopyranosyl)- $\alpha$-D-ribopyranose (A2B3GalR) and 1,4-anhydro-2-O-benzyl-3-O-(2',3',6',2", 3",4",6"-hepta- $O$ benzyl- $\beta$-D-lactosyl)- $\alpha$-D-ribopyranose (A2B3LR).

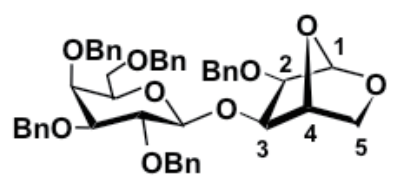

A2B3GalR

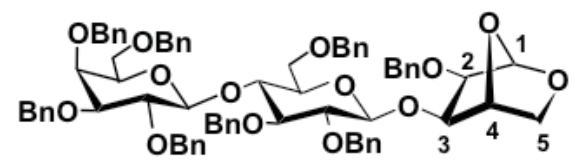

A2B3LR

The disaccharide monomer A2B3GalR gave stereoregular 1,5- $\alpha$ polymers with a high molecular weight, $\overline{\mathbf{M}}_{\mathrm{n}}=$ $43.0 \times 10^{3}$, in good yields. After deprotection, a stereoregular 1,5 - $\alpha$-D-ribofuranan main chain having a $\beta$-D-galactopyranose branch in every repeating unit was obtained. The trisaccharide monomer A2B3LR was found to have high polymerizability with $\mathrm{BF}_{3} \mathrm{OEt}_{2}$ as a catalyst to give the corresponding lactosebranched ribofuranans after deprotection to recover hydroxyl groups. These branched polysaccharides with defined structures should be useful model branched polysaccharides to study the relationship between structure and biological activity $(20,21)$.

\section{Sulfated Polysaccharides with Antiviral Activity}

It is well known that sulfated polysaccharides in nature
凝血作用 $(\mathrm{AA}=18$ and $13 \mathrm{unit} / \mathrm{mg})$ を示した。これらの值は 標準の硫酸化糖鎖として用いているデキストラン硫酸 $\left(\mathrm{EC}_{50}=\right.$ $0.84 \mu \mathrm{g} / \mathrm{ml}$ and $\mathrm{AA}=22.9 \mathrm{unit} / \mathrm{mg})$ とカードラン硫酸 $\left(\mathrm{EC}_{50}=\right.$ $0.13 \mu \mathrm{g} / \mathrm{ml}$ and $\mathrm{AA}=19 \mathrm{unit} / \mathrm{mg})$ の值と比較して求めたもの である。ラクトースとグルコースとの共重合体 17 では主鎖の ラクトースユニットの割合が低くなるに従ってそれらの生理 活性は高くなるこが分かった。15\%の割合でラクトースユニッ 卜を持つ硫酸化した共重合体では、それぞれ、抗 HIV 作用が $0.3 \mu \mathrm{g} / \mathrm{ml}$ 、抗凝血作用が $54 \mathrm{unit} / \mathrm{mg}$ と高い生理活性を示した。 細胞毒性 $\left(\mathrm{CC}_{50}\right)$ は $276 \mu \mathrm{g} / \mathrm{ml}$ となり $(276 \mu \mathrm{g} / \mathrm{ml}$ 以上加えて も50\%の細胞は正常に増殖）低いことが分かった。この生理 活性の結果は枝と枝との間の距離が硫酸化糖鎖の抗 HIV 作用 や抗凝血作用にとって重要な役割を担っていることを示して いる。

多くの無水糖モノマーのうち、我々は高い開環重合性を持

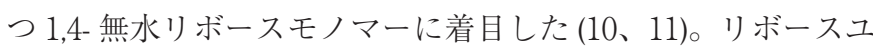
ニットが主鎖になり各リボースユニットからガラクトースお よびラクトースの枝が生えた二糖モノマー、三糖モノマーの 1 , 4- アンヒドロ -2-O-ベンジル -3-O-(2,3,4,6- テトラ - O-ベンジル - $\beta$-D- ガラクトピラノシル ) $\alpha$-D- リボピラノース (A2B3GalR) 、1, 4- アンヒドロ -2-O-ベンジル -3-O-(2',3',6',2",3",4",6"- ヘプタ -O- ベ ンジル - $\beta$-D-ラクトシル )- $\alpha$-D- リボピラノース (A2B3LR)を成

Fig.2. Galactose and lactose branched diand trisacchacide ribose monomers

した。無水二糖モノマーA2B3GalR は高い開環重合性を示し、 分子量 $\overline{\mathbf{M}}_{\mathrm{n}}=43.0 \times 10^{3}$ を持つ 1,5- $\alpha$ 構造のポリマーを与えた。 脱ベンジル化後、1,5- $\alpha$-D- リボフラナンの主鎖に 1 つつのリ ボースユニットに対し 1 つの-D-ガラクトースの枝を持つ糖 鎖が得られた。また、無水三糖モノマーの A2B3LR も三フッ 化ホウ素エーテル $\left(\mathrm{BF}_{3} \mathrm{OEt}_{2}\right)$ 触媒で高い開環重合性を示し、脱 ベンジル化後、対応する二糖のラクトースが分枝したリボフ ラナンを与えることが分かった。これらの分枝構造を持つ糖 鎖は構造明確であり糖鎖構造と生理活性との関係を調べるた めに有効なモデル糖鎖になる $(20 、 21) 。$

\section{C . 抗ウイルス性を持つ硫酸化糖鎖}

上に述べてきたように、天然では硫酸化糖鎖は抗ウイルス 
have specific biological activities such as blood anticoagulant and antiviral activities. In 1958, Gerber found for the first time that sulfated polysaccharides extracted from sea alga had antiinfluenza virus activity (22). In 1987, Professors Yamamoto and Nakashima found the anti-HIV activity of sulfated polysaccharides also extracted from sea alga (23). However, to our knowledge, there are no reports on the antiviral activities of synthetic sulfated polysaccharides and also no reports on the relationship between the structure of polysaccharides and biological activities.

We reported in 1987 that three synthetic sulfated polysaccharides, dextran sulfate, ribofuranan sulfate, and xylofuranan sulfate had potent anti-HIV activity at concentrations as low as $3.3 \mu \mathrm{g} / \mathrm{ml}$ (24). In 1990, we carried out the sulfation of curdlan which is a natural polysaccharide with a linear $(1 \rightarrow 3)-\beta$-D-glucopyranosidic structure produced by a fungus. Curdlan sulfate was found to have potent antiHIV activity below $3.3 \mu \mathrm{g} / \mathrm{ml}$ and the lowest cytotoxicity at more than $1000 \mu \mathrm{g} / \mathrm{ml}(1)$.

Recently, it was reported that two sulfated polysaccharides from the red seaweeds selectively inhibited dengue virus (DENV) in different host cell types (25). The sulfated polysaccharides inhibited the multiplication of DENV-2 in Vero cells with a 50\% inhibitory concentration $\left(\mathrm{IC}_{50}\right)$ at around $1 \mu \mathrm{g} / \mathrm{ml}$. However, the sulfated polysaccharides had lower $\mathrm{IC}_{50}$ values for DENV-3 and DENV-4, in the range $13.9 \sim 14.2 \mu \mathrm{g} / \mathrm{ml}$ and $29.3 \sim 50 \mu \mathrm{g} /$ $\mathrm{ml}$, respectively, and they were inactive against DENV-1. On the host cells, the sulfated polysaccharides had similar effective anti-DENV-2 and -3 activities in human hepatoma HepG2 and foreskin PH cells as in Vero cells, but they were inactive in mosquito C6/36 HT cells. These variations may be ascribed to differences in the virus-cell interaction leading to virus entry. Recently, a Chinese group at Shantou University reported in vitro anti-influenza virus activity of sulfated polysaccharides extracted from sea alga, suggesting that the sulfated polysaccharides had higher antiviral activity in the range $\mathrm{IC}_{50}=2.96 \sim 15.99 \mu \mathrm{g} / \mathrm{ml}$ without significant cytotoxicity (26). A Japanese group of Toyama University also reported the antiviral activities of an edible blue-green alga on the replication of herpes simplex virus- 2 and influenza A virus at the concentrations of $\mathrm{IC}_{50}=0.32 \sim 190 \mu \mathrm{g} / \mathrm{ml}$ and $0.79 \sim 65$ $\mu \mathrm{g} / \mathrm{ml}$, respectively (27). The activity was dependent on the timing of addition of the extracts, and the addition of sulfated polysaccharides to the medium at the same time as viral infection was more effective than addition immediately after infection. These results suggest that sulfated polysaccharides had the inhibition on the stage of virus absorption and subsequent infection to cells. The same Japanese group also reported the antiviral polysaccharides, nostoflan, from a terrestrial cyanobacterium (28). Nostoflan exhibited a potent
性や抗凝血作用など特異な生理活性を持つことが知られてい る。1958 年に Gerbar らは海藻からの硫酸化多糖類が抗インフ ルエンザウイルス作用を持つことを見出した (22)。1987 年に は山本直樹教授と中島秀喜教授は同じく海藻からの硫酸化糖 鎖に抗 HIV 作用があることを明らかにした (23)。しかし、合 成で得られた構造明確な硫酸化糖鎖の抗ウイルス性や構造と 生理活性との関係を明らかにした研究は、これまでにあまり 報告されていないようである。

1987 年に我々は合成で得られた硫酸化糖鎖、デキスト ラン硫酸、リボフラナン硫酸、キシロフラナン硫酸は高い抗 HIV 作用を持ち、3.3 $\mu \mathrm{g} / \mathrm{ml}$ の低濃度で HIV の感染を完全に 抑制することを見出した (24)。また、1990 年には (1 $\rightarrow 3)-\beta$-Dグルコピラノース構造を持つ天然の直鎖状多糖類、カードラ ンを硫酸化して得たカードラン硫酸が最も高い抗 HIV 作用 (3.3 $\mu \mathrm{g} / \mathrm{ml})$ を示し、最も低い細胞毒性 $(1000 \mu \mathrm{g} / \mathrm{ml}$ 以上 ) である ことを見出した $(1)$ 。

最近、海藻から抽出された 2 つ硫酸化多糖類がデング 熱ウイルス (DENV) に対し異なったホスト細胞において効果 が高いことが報告された (25)。それらの硫酸化糖鎖はべロ細 胞中で DENV-2 ウイルスの増殖を約 $1 \mu \mathrm{g} / \mathrm{ml}$ (IC50) の濃度 で抑制した。しかしながらこれらの硫酸化糖鎖は DENV-3 と DENV-4 ウイルスに対しては $\mathrm{IC}_{50}$ の值が $13.9 \sim 14.2 \mu \mathrm{g} / \mathrm{ml}$ and $29.3 \sim 50 \mu \mathrm{g} / \mathrm{ml}$ となりそれほど高い効果を示さなかっ た。さらにDENV-1 ウイルスに対しては効果を示さなかった。 また、ヒトのヘパトーマ (hepatoma) HepG2 細胞とフォースキ ン (foreskin) PH 細胞ではべロ細胞中と同様な DENV-2 ウイル スと DENV-3 ウイルスに対して効果が認められたが、C6/36 HT 細胞中では効果がなかった。これらの相違はウイルスが感 染する際のウイルスと細胞との相互作用の違いに由来してい ると推定している。また、中国の研究者は海藻からの硫酸化 糖鎖に抗インフルエンザウイルス作用が認められたと報告し た (26)。これらの硫酸化糖鎖は特段の細胞毒性を示すことなく 高い活性、 $\mathrm{IC}_{50}=2.96 \sim 15.99 \mu \mathrm{g} / \mathrm{ml}$ を持っていた。日本の研 究者は海藻から得られた硫酸化糖鎖はへルペスウイルスとイ ンフルエンザウイルスに対してそれぞれ高い効果（ $\mathrm{IC}_{50}=0.32$ 〜 $190 \mu \mathrm{g} / \mathrm{ml}$ 抒よび $0.79 \sim 65 \mu \mathrm{g} / \mathrm{ml}$ ) を持つことを報告し た (27)。そして活性は抽出した硫酸化糖鎖の加えるタイミング によることも報告し、硫酸化糖鎖の加えるタイミングはウイ ルスを細胞に感染させた直後に加えるよりも先に細胞溶液に 加えておいた方が効果的であることも示した。このことはウ イルスが細胞に吸着・感染する段階を硫酸化糖鎖が阻害して いることを示している。同じ日本の研究者は抗ウイルス性多 糖類をバクテリアから抽出しナストフランと命名した (28)。ナ ストフランはヘルペスウイルス HSV-1 に対して高い効果があ 
anti-HSV-1 (herpes simplex virus type-1) activity with an $\mathrm{IC}_{50}$ of $0.37 \mu \mathrm{g} / \mathrm{ml}$, and also potent antiviral activities against HSV-2 $(29 \mu \mathrm{g} / \mathrm{ml})$, human cytomegalovirus $(0.47 \mu \mathrm{g} / \mathrm{ml})$, and influenza A virus $(78 \mu \mathrm{g} / \mathrm{ml})$. However, no effect was observed on adenovirus or coxsackie virus. Therefore, nostoflan has antiviral activity against enveloped viruses whose cellular receptors are carbohydrates. Nostoflan is composed of two types of sugar sequences and showed no antithrombin activity, unlike sulfated polysaccharides, because it has no sulfate groups in the polysaccharide molecule.

Several papers on the development of carbohydrate clusters using dendrimers have been published (29). Dendritic compounds with polylysine or carbosilane core scaffolds with sialic acid on their surface were potent inhibitors of influenza viruses, depending on cluster effects (30). Influenza virus is infected into the cells by a target of sialic acid on the surface of cells. An acyclic oligopeptide from HIV connects to cellobiose on the surface of a polylysine dendrimer (31). This type of dendrimer may become an AIDS vaccine. Negatively-charged sulfated oligosaccharides on the surface of the dendrimer were expected to have high biological activities due to both ionic interaction and the cluster effect on the positively charged surface proteins of viruses. We recently described the synthesis of a polylysine dendrimer with sulfated cellobiose and evaluated its anti-HIV and blood anticoagulant activities $(32,33)$. A relationship between the structure and biological activities was reported. Polylysinedendritic sulfated cellobiose was synthesized by sulfation of polylysine-dendritic cellobiose, which had been prepared from cellobiose and polylysine dendrimer generation 3 . The degree of sulfation was 1.85 per glucose unit (maximum 3 ). The molecular weights measured by GPC were $\overline{\mathrm{M}}_{\mathrm{w}}=12.4 \times 10^{3}$ and $\overline{\mathrm{M}}_{\mathrm{n}}=10.4 \times 10^{3}$, suggesting that the sulfated cellobiose dendrimer had a very compact structure. The anti-HIV activity was assayed in vitro by the MTT method, which indicated that the $\mathrm{EC}_{50}=3.2 \mu \mathrm{g} / \mathrm{ml}$ for the $50 \%$ inhibitory concentration of virus replication, a concentration that is as high as that of the currently clinical used AIDS drug, $\operatorname{ddC}\left(\mathrm{EC}_{50}=3.51 \mu \mathrm{g} / \mathrm{ml}\right)$, and has low cytotoxicity $\left(\mathrm{CC}_{50}=1000 \mu \mathrm{g} / \mathrm{ml}\right)$. The blood anticoagulant activity determined by the method of the United States Pharmacopoeia was AA $=19.4$ unit $/ \mathrm{mg}$, the same as that of the sulfated polysaccharides, dextran sulfate (AA = $22.9 \mathrm{unit} / \mathrm{mg}$ ) and curdlan sulfate (AA = $19 \mathrm{unit} / \mathrm{mg}$ ). These results suggest that the biological activities were improved by a cluster effect of the sulfated cellobiose that originated from the dendritic structure because sulfated oligosaccharides have little anti-HIV activity.

Recently, we prepared a membrane filter coated with curdlan sulfate to remove influenza virus. A long alkyl chain from didodecyldimethylammonium bromide was introduced
ることを示し $\left(\mathrm{IC}_{50}=0.37 \mu \mathrm{g} / \mathrm{ml}\right) 、$ 同様に HSV-2 $(\mathrm{IC} 50=29$ $\mu \mathrm{g} / \mathrm{ml})$ やヒトサイトメガロウイルス $\left(\mathrm{IC}_{50}=0.47 \mu \mathrm{g} / \mathrm{ml}\right)$ に対 しても効果が高かったが、インフルエンザウイルスに対して は $\mathrm{IC}_{50}=78 \mu \mathrm{g} / \mathrm{ml}$ であった。しかし、アデノウイルスやコク サキーウイルスに効果は示さなかった。このことは、ナスト フランは細胞のレセプターに糖鎖を持つ表皮ウイルスに対し て効果的であることを示している。そしてナストフランは 2 つの形の糖鎖からできて抢り、硫酸化糖鎖のような抗血栓性 は示さなかったので、その糖鎖中には硫酸基が存在していな いと考えた。

糖鎖を用いたデンドリマーの開発に関する報告がされた (29)。ポリリジンやカーボシラン骨格表面にシアル酸を持つデ ンドリマーはクラスター効果によって高い抗インフルエンザ ウイルス作用を持つことが示された (30)。インフルエンザウイ ルスは細胞表面にあるシアル酸をターゲットとして細胞に感 染する。また、HIVの表皮タンパクをもとにして合成したオ リゴペプチドを環状にしてデンドリマー表面に結合させた構 造を構築した報告もある (31)。これはエイズワクチンになると 期待できる。(-) 電荷の硫酸化オリゴ糖鎖を表面に持つデン ドリマーは、表皮タンパクに由来する $(+)$ 電荷を持つウイルス に対してイオン的な相互作用とクラスター効果の両方によっ て高い生理活性が期待できる。我々は最近、硫酸化セロビオー スユニットを表面に持つポリリジンデンドリマーを合成し、 高い抗 HIV 作用と抗凝血作用を示し (32、33)、構造と生理活 性との関係を明らかにした。このセロビオースデンドリマー はポリリジンデンドリマー第 3 世代とセロビオースから合成 し、硫酸化度はグルコース 1 コあたり 1.85 （最高は 3）である。 GPC で測定した分子量は $\overline{\mathrm{M}}_{\mathrm{W}}=12.4 \times 10^{3}$ および $\overline{\mathrm{M}}_{\mathrm{n}}=10.4$ $\times 10^{3}$ となりコンパクトな構造を持つことが明らかになった。 抗 HIV 作用はこれまでと同様に MTT 法によって行った。そ れによると、硫酸かしたデンドリマーの $50 \%$ 感染を抑制する 濃度は、 $\mathrm{EC}_{50}=3.2 \mu \mathrm{g} / \mathrm{ml}$ となり、現在エイズ薬として使わ れている $\mathrm{ddC}$ の值、 $\mathrm{EC}_{50}=3.51 \mu \mathrm{g} / \mathrm{ml}$ とほぼ同じ高い抗 HIV 作用を示すことが分かった。さらに細胞毒性は低かった $\left(\mathrm{CC}_{50}\right.$ $=1000 \mu \mathrm{g} / \mathrm{ml})$ 。また、抗凝血作用は $\mathrm{AA}=19.4 \mathrm{unit} / \mathrm{mg}$ とな りデキストラン硫酸 (22.9 unit/mg) やカードラン硫酸 (19 unit/ $\mathrm{mg})$ の值とほぼ同じ低いことが分かった。硫酸化セロビオー ス自身には高い抗 HIV 性などの生理活性はないので、この結 果は硫酸化セロビオースのクラスター効果によって高まった ことを示している。

最近、我々はカードラン硫酸を固定化させて作製したメ ンブランフィルター $(1 \mu \mathrm{m}$ の細孔 $)$ が効率的にインフルエンザ A ウイルスを吸着し除去できることを見出した (34)。メンブラ ンフィルターの疎水性表面に親水性のカードラン硫酸を固定 化させるために長鎖アルキル鎖をカードラン硫酸にイオン結 
into curdlan sulfate by the ionic interaction between the negative sulfate group and positive ammonium salt with a didodecyldimethyl group to give alkyl curdlan sulfates with various degree of alkylation (34). The alkyl curdlan sulfate with the degree of alkylation of 0.03 (1 alkyl group in 12 sugar units) had potent anti-HIV activity at concentrations as low as $\mathrm{EC}_{50}=0.87 \mu \mathrm{g} / \mathrm{ml}$, a $50 \%$ effective concentration. Coating the alkyl curdlan sulfate on a membrane filter (pore size: $1 \mu \mathrm{m}$ ) gave a curdlan sulfate-coated membrane filter due to the hydrophobic interaction between the long alkyl groups and the surface of the filter. The membrane filter has pores with a diameter around $10 \mu \mathrm{m}$ on the surface as observed by SEM. It was found that the three sheets of the membrane filter coated with $1.6 \mathrm{mg}$ of alkyl curdlan sulfate selectively removed influenza $A$ viruses at dilutions below 1/32. However, the membrane filter did not effectively remove on influenza $\mathrm{B}$ viruses. The removal mechanism was assumed to be due to the adsorption of influenza A viruses on the curdlan sulfatecoated membrane filter by the electrostatic interaction between negatively charged sulfate groups and a positively charged envelope protein, hemagglutinin, of the A viruses (Scheme 7).
合で導入した。長鎖アルキル鎖とメンブランフィルター表面 との疎水的相互作用によってカードラン硫酸を固定化させた。 長鎖アルキル鎖の割合が 0.03 （12糖残基あたり 1 本の長鎖ア ルキル鎖を導入）のものは $50 \%$ 感染を抑制する濃度で高い抗 $\mathrm{HIV}$ 作用、 $\mathrm{EC}_{50}=0.87 \mu \mathrm{g} / \mathrm{ml}$ を示すことが分かった。 SEM 写真によってカードラン硫酸を固定化したメンブランフィル ターは表面の $10 \mu \mathrm{m}$ の細孔を持つことが分かった。ウイルス の直径は最大でも $0.4 \mu \mathrm{m}$ 程度なのでカードラン硫酸を固定 化させたメンブランフィルターはろ過ではなく静電的な相互 作用による吸着によってウイルスを除去しているものと推定 した。カードラン硫酸 $1.6 \mathrm{mg}$ を固定化したメンブランフィル ターを 3 枚用いると少なくともインフルエンザウイルス濃度 を 1/32 以下に低下させることが分かった。インフルエンザ A ウイルスの除去のメカニズムは上に述べた通りカードラン硫 酸の（－）電荷とインフルエンザ A ウイルス表皮タンパクヘ マグルニチンに由来する $(+)$ 電荷間の静電的相互作用によって ウイルスが吸着され取り除かれるものと推定した (Scheme 7)。 しかし、インフルエンザBウイルスに対しては効果を示さな かったので、A ウイルスと B ウイルスの表皮タンパクの構造 に違いがあるのではと推定し、現在検討を進めている。

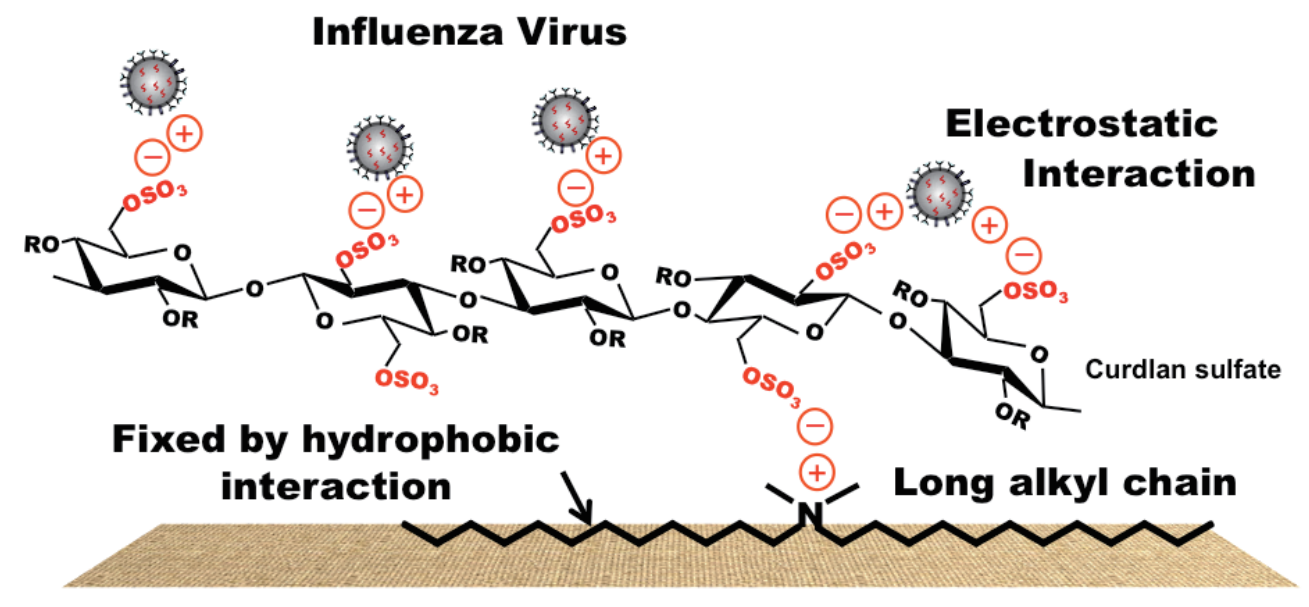

Membrane filter

Scheme 7. Illustrated image of the interaction between curdlan sulfate and influenza A virus.

\section{Relationship between Structure and Biological Activities of sulfated polysaccharides}

Determining the interaction mechanism between sulfated polysaccharides and proteins is important for the development of biomaterials. Surface plasmon resonance (SPR) is one means to quantitatively investigate the relationships. Scheme 8 illustrated the mechanism of SPR apparatus. The change of weight after interaction between analyte and ligand is continuously monitored by the SPR signal and the interaction is calculated quantitatively.

Many investigations of the relationship between
D. 硫酸化糖鎖の構造と生理活性との関係

硫酸化糖鎖とタンパク質間の相互作用メカニズムの決定 は生医学材料化を開発するためにたいへん重要である。表面 プラズモン共鳴 (SPR) 装置はその関係を定量的に調べることが できる装置である。Scheme 8 はSPR 装置の模式図であるが、 アナライトとリガンドとの相互作用によって生ずる質量変化 をSPR シグナルとして連続的に記録し、相互作用を定量的に 計算できる装置である。

SPR を用いるタンパク質とタンパク質、核酸とタンパク 
Scheme 8. Illustrated scheme of SPR. The analyte is flowed in a flow cell and across the immobilized ligand on the sensorchip. The change of weight on the sensorchip after interaction is detected by SPR signal.

protein-protein, nucleic acid- protein, carbohydrate-protein, and carbohydrate-carbohydrate interactions using SPR have been reported. Among them, there are many papers on heparin-protein interactions. Heparin is a natural sulfated polysaccharide with complex branched structures that has a potent blood anticoagulant activity. Ronald and Coombe of Curtin University of Technology in Australia reported the heparin-protein interactions by means of SPR (35). Biotin was connected to the reducing terminal of heparin (EP-heparin) and then heparin was immobilized through biotin on the SA sensor chip with a thin layer of dextran bearing carboxylic acids. The analytes, lactoferrin, antithrombin III, avidin, and thrombin, at various concentrations in buffer solutions were flowed over the heparin-immobilized sensor chip, respectively, and the interactions were measured by SPR . Two other biotinylated heparin derivatives, $\mathrm{NH}_{2}$-heparin and $\mathrm{COOH}$-heparin, which were obtained by the connection of biotin to the $\mathrm{NH}_{2}$ and $\mathrm{COOH}$ groups in heparin, respectively, were synthesized and the interactions measured by SPR. The EP-heparin was found to have the highest binding capacity of each of the proteins. The $\mathrm{NH}_{2}$-heparin had an intermediate binding capacity, and the $\mathrm{COOH}$-heparin had the lowest. These results suggest that the biological activity of heparin requires a specific and defined heparin sulfation pattern for binding. Furthermore, French researchers identified the heparin binding domains of the HIV-1 envelope glycoprotein gp120 by SPR (36). The interaction was attributed mainly to the V3 loop in gp120. However, the researchers found three additional binding domains in the gp120 on heparin, in which four binding domains were identified in the V2 and V3 loops, in the C-terminal domain, and within the CD4induced bridging sheet. Shen and coworkers of University Clinic in Australia described the evaluation of binding affinity of several natural sulfated polysaccharides including heparin against human neutrophil elastase (HNE), hyaluronidase (HAase), and lysozyme (37). The results showed the ranking of binding affinities of several acidic polysaccharides to HNE,

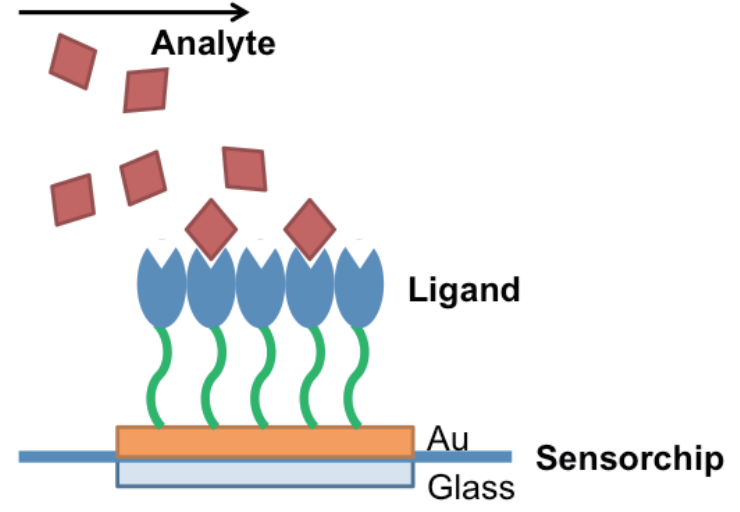

質、糖鎖とタンパク質との相互作用など多くの研究が報告さ れている。それらの研究の中で抗凝血作用を持つ天然の硫酸 化糖鎖ヘパリンとタンパク質との相互作用に関する研究が数 多く発表されている。ロナルドとコンビはへパリンとタンパ ク質との相互作用を SPR を用いて研究した (35)。ビオチンを ヘパリンの末端に導入しSA センサーチップ表面に固定化した もの (EP-ヘパリン)を作製した。相互作用を観測したいタン パク質（アナライト）としてラクトフェリン、抗凝血因子で あるアンチトロンビンIII、アビディン、凝固因子のトロンビ ンを用いてセンサーチップ上に固定化させたへパリンとの相 互作用を SPR 装置を用いて観測した。さらにビオチンをへパ リンのアミノ基に結合させた $\mathrm{NH}_{2}$ ヘペリン、カルボキシル基 に結合させた COOH-ヘパリンも合成し相互作用の相違を検討 した。その結果、EP-ヘパリンが各タンパク質に関して最も高 い相互作用を示すことが分かった。 $\mathrm{NH}_{2}$ ヘパリンは中間の值、 COOH-ヘパリンは低い相互作用であった。これらの結果はへ パリンの生理活性が特異的である硫酸化のパ夕ーンが夕ンパ ク質との結合に必要であることを示している。さらにフラン スの研究者はSPRによってヘパリンが HIV-1 ウイルスの表皮 タンパク gp120のどのドメインに結合するのかを調べた (36)。 その結果、相互作用は gp120 中の V3 ループに主に存在する と推定した。彼らはへパリンの結合ドメインに関してさらに 3つのドメインの存在を明らかにした。すなわち、それらは gp120 表皮タンパク中の V2 ループ、C- 末端、およびCD4を 誘起する架橋シート中に見出した。オーストラリアの研究グ ループはヘパリンを含むいくつかの天然硫酸化糖鎖といくつ かの酵素との相互作用を調心゙、硫酸化糖鎖の相互作用しやす さを報告した (37)。そのうち、ケラタン硫酸のみが他の硫酸化 
HAase, and lysozyme, respectively. Although keratin sulfate (KS) had strong binding affinity to lysozyme, KS showed low affinity to HNE and HAase.

The anti-HIV activity of sulfated polysaccharides originates from the electrostatic interaction between negatively charged sulfate groups of sulfated polysaccharides and the positively charged envelope glycoprotein gp120 on the HIV surface (38). This mechanism was estimated in vivo by using recombinant gp120 (39) and in vitro by using NMR spectroscopy $(40,41)$. Taking into account the interaction mechanisms, ionic interactions play an important role in the enhancement of biological activities. Recently, we reported quantitatively the interaction between synthetic sulfated polysaccharides with defined structures and poly-L-lysine as a model compound of proteins to investigate the quantitative relationship between the two biomacromolecules $(42,43)$. The interaction was observed using a Biacore X100 SPR biosensor at $25^{\circ} \mathrm{C}$. Poly-L-lysine was immobilized on a CM5 sensor chip using the amine coupling kit as described by the manufactures instructions. Dextran sulfates at various concentrations were injected into the flow cell at a flow rate of $30 \mu \mathrm{l} / \mathrm{min}$ and then the interaction was measured after 2 min as the binding response (RU) as shown in Fig. 3. The binding affinity was found to increase with increasing degree of sulfation of

Fig.3. Binding of dextran sulfates with various degree of sulfation to immobilized poly-L-lysine. Dextran sulfate $(1.25 \mathrm{mg} / \mathrm{ml})$ was injected over the sensorchip immobilized poly-L-lysine.

dextran sulfate, and the interacting dextran sulfate was not removed from the sensor chip, suggesting that dextran sulfate interacted strongly with poly-L-lysine. The binding affinity also increased with the increasing molecular weight of dextran sulfate. The association-rate $\left(k_{\mathrm{a}}\right)$, dissociation-rate $\left(k_{\mathrm{d}}\right)$, and dissociation $\left(K_{\mathrm{D}}\right)$ constants between dextran sulfates and polyL-lysine were $k_{\mathrm{a}}=6.92 \times 10^{4} \sim 2.08 \times 10^{6}(1 / \mathrm{Ms}), k_{\mathrm{d}}=1.37 \times$ $10^{-4} \sim 5.58 \times 10^{-5}(1 / \mathrm{s})$, and $K_{\mathrm{D}}=8.77 \times 10^{-11} \sim 1.63 \times 10^{-9}(\mathrm{M})$, respectively. These results indicate that the two compounds interacted strongly by the electrostatic interaction between negatively charged sulfate groups in dextran sulfates and positively charged amino groups in poly-L-lysine.
糖鎖のタンパク質との相互作用の傾向が異なっていた。ケラ タン硫酸はヒト HNE と HAase に対して相互作用は低かった。 硫酸化糖鎖の抗 HIV 作用は硫酸基に由来する（- ）電荷 と HIV の表皮タンパク gp120 中の塩基性アミノ酸集中部位に

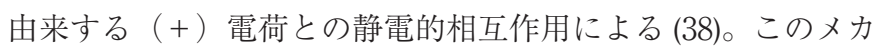
ニズムは遺伝子組換 gp120を用いるin vivo の実験 (39) および NMR を用いるin vitro の実験 (40、41) から推定された。この 相互作用メカニズムから考光、イオン的な相互作用は硫酸化 糖鎖の生理活性にとって重要と認識される。最近、我々は構 造明確な合成硫酸化糖鎖とタンパク質のモデル化合物として


間の定量的関係を検討した (42、43)。その相互作用はビアコア X100SPR 装置を用いて $25^{\circ} \mathrm{C} て ゙$ 観測したものである。メーカー 指定の方法によりアミンカップリングキットを用いてポリ-LリジンをCM5 センサーチップ上に固定化して実験を行った。 図 3 に示すように種々の濃度でデキストラン硫酸をフローセ ル中に導入し緩衝溶液を $30 \mu \mathrm{l} / \mathrm{min}$ の流速で流し 2 分後から 結合レスポンス（RU）として相互作用を測定した。結合の親



和性はデキストラン硫酸の硫酸化度が大きくなるにつれて増 加し、ポリ-L-リジンと相互作用したデキストラン硫酸はセン サーチップ上から外れることはなかった。また結合の親和性 はデキストラン硫酸の分子量が大きくなれにつれても増加し た。このときのデキストラン硫酸とポリ -L-リジンとの間の結 合速度定数は $k_{\mathrm{a}}=6.92 \times 10^{4} \sim 2.08 \times 10^{6}(1 / \mathrm{Ms})$ 、解離速度 定数は $k_{\mathrm{d}}=1.37 \times 10^{-4} \sim 5.58 \times 10^{-5}(1 / \mathrm{s})$ 、解離定数は $K_{\mathrm{D}}=$ $8.77 \times 10^{-11} \sim 1.63 \times 10^{-9}(\mathrm{M})$ となった。この結果はデキスト ラン硫酸の硫酸基に基づく $(-)$ 電荷とポリ -L-リジンの $(+)$ 電荷との間の静電的相互作用によって $2 つ の$ 化合物はたいへ ん強く相互作用していることが定量的に明らかとなった。 


\section{E. Perspective}

We described recent developments in studies of sulfated polysaccharides in focusing on the synthesis, activities, and elucidation of their interactions. Sulfated polysaccharides not only have specific biological activities, such as antiviral and blood anticoagulant activities, but also are expected to become new biomaterials. For their use as biomaterials, it is important to elucidate the action mechanisms. Polysaccharideprotein interactions are widely involved in serious diseases such as cancer and infectious diseases. The SPR and NMR methods are powerful tools to investigate the mechanisms in vitro. We continue to develop new sulfated polysaccharides and elucidate quantitatively their interaction with proteins and peptides.

\section{Acknowledgment}

We are particularly indebted to Professor Toshiyuki

Uryu for his valuable discussions and continuing encouragement.

\begin{abstract}
$E$. 今後について
このミニレビューでは最近の硫酸化糖鎖の研究について 合成、生理活性、相互作用などを中心に述べた。硫酸化糖鎖 は抗ウイルス性や抗凝血作用など特異な生理活性を持つこと だけではなく新しい生医学材料としても期待されているもの である。生医学材料として用いる場合にはその作用メカニズ ムを解明することが重要となる。糖鎖とタンパク質間の相互 作用はガンや感染症などたいへん広い範囲で関係していると 考えられている。SPRやNMR を用いることはin vitroでそれ らのメカニズムを解明するためにたいへん有効な手段である。 我々は引き続き新しい糖鎖の合成とタンパク質やペプチドと の定量的な相互作用の解析について研究を進めている。
\end{abstract}

謝 辞

本研究を推進するにあたり貴重な研究討論と励ましを頂 いている瓜生敏之教授（東京大学名誉教授）に感謝申し上げ ます。

\section{References}

1. Yoshida, T., Hatanaka, K., Uryu, T., Kaneko, Y., Yasuda, N., Mimura, T., Yoshida, O., and Yamamoto, N. (1990) Macromolecules 23, 3717 -3722 .

2. Lane, D. A., and Lindahl, U. (1989) Heparin, Chemical Properties Clinical Applications. Edward Arnold, London.

3. Ruckel, E. R., and Schuerch, C. (1966) J. Org. Chem. 31, 2233-2238.

4. Schuerch, C. (1972) Adv. Polym. Sci. 10, 173-194.

5. Schuerch, C. (1981) Adv. Polym. Sci. 39, 157-212.

6. Okada, M. (1992) Adv. Polym. Sci. 102,1-46.

7. Uryu, T. (1990) in Models of biopolymers by ring-opening polymerization (Penczek, S., Ed.), pp. 133-233, CRC Press, Boca Raton.

8. Uryu, T (1993) Prog. Polym. Sci. 18, 717-761.

9. Yoshida T (2001) Prog. Polym. Sci. 26, 379-441.

10. Uryu, T., Kitano, K., Ito, K., Yamanouchi, J., and Matsuzaki, K. (1981) Macromolecules 14, 1-9.

11. Uryu, T., Yamanouchi, J., Kato, T., Higuchi, S., and Matsuzaki, K. (1983) J. Am. Chem. Soc. 105, 6865-6871.

12. Hattori, K. and Yoshida, T. (2009) Macromolecules 42, 6044-6049.

13. Yoshida, D., and Yoshida, T. (2009) J. Polym. Sci. Part A: Polym. Chem. 47, 1013-1022.

14. Choi, Y., Yoshida, T., and Uryu, T. (1997) Macromol. Chem. Phys. 198, 2875-2888.

15. Uryu, T., Yamanouchi, J., Hayashi, S., Tamaki, H., and Matsuzaki, K. (1983)Macromolecules 16, 320-326.

16. Veruovic. B., and Schuerch, C. (1970) Carbohydr. Res. 14, 199-206.

17. Masura, V., and Schuerch, C. (1972) Carbohydr. Res. 15, 65-72.

18. Kobayashi, K., Nomura, K. and Okada, M. (1993) Carbohydr. Res. 242, 161-166.

19. Han, S., Kanematsu, Y., Hattori, K., Nakashima, H. and Yoshida, T. (2009) J. Polym. Sci. Part A: Polym. Chem. 47, $913-924$.

20. Yoshida, T. and Endo, K. (2001) Macromol. Biosci. 1, 298-304.

21. Yoshida, D., Han. S., Narita, K., Hattori, K., and Yoshida, T. (2009) Macromol. Biosci. 9, 687-693.

22. Gerber, P., Dutcher, J. D., Adams, E. V., and Sherman, J. H. (1958) Proc. Soc. Exp. Biol. Med. 99, $590-593$.

23. Nakashima, H., Kido, Y., Kobayashi, N., Motoki, Y., Neushul, M., and Yamamoto, N. (1987) J. Cancer Res. Clin. Oncol. 113, $413-416$.

24. Nakashima, H., Yoshida, O., Tochikura, T., Yoshida, T., Mimura, Y., Kido, Y., Motoki, Y., Kaneko, T., Uryu, T., and Yamamoto, N. (1987) Jpn. J. Cancer Res. (Gan) 78, 1164-1168.

25. Talarico, L. B., Pujol, C. A., Zibetti, R. G. M., Faria, P. C. S., Noseda, M. D., Duarte, M. E. R., and Damonte, E. B. (2005) Antiviral Res. 66, 103-110.

26. Chen, M., Xie, H., Yang, L., Liao, Z., and Yu, J. (2010) Virologica Sinica 25, 341-351.

27. Ogura, F., Hayashi, K., Lee, J., Kanekiyo, K., and Hayashi, T. (2010) Biosci. Biotechnol. Biochem. 74, 1687-1690.

28. Kanekiyo, K., Lee, J., Hayashi, K., Takenaka, H., Hayakawa, Y., Endo, S., and Hayashi, T. (2005) J. Nat. Prod. 68, $1037-1041$.

29. Newkome, G.R., Moorefield, C.N., and Vögtle, F. (2003) Dendrimers and Dendrons, Wiley-VCH, Weinheim.

30. Roy, R., Pon, R.A., Tropper, F. D., and Andersson, F. O. (1993) J. Chem. Soc. Chem. Commun. 3, $264-265$.

31. Baigude, H., Katsuraya, K., Okuyama, K., and Uryu, T. (2004) Macromol. Chem. Phys. 205, 684-691.

32. Han, S. Baigude, H. Hattori, K. Yoshida, T. and Uryu, T. (2007) Carbohydr. Polym. 68, 26-34.

33. Han, S. Yoshida, T. and Uryu, T. (2007) Carbohydr. Polym. 69, 436-444. 
34. Tegshi, M., Han, S., Kanamoto, T., Nakashima, H., and Yoshida, T. (2011) J. Polym. Sci. Part A: Polym. Chem. 49, $3241-3247$.

35. Osmond, R. I. W., Kett, W. C., Skett, S. E., Coombe, D. R. (2002) Anal. Biochem. 310, 199-207.

36. Crublet, E., Andrieu, J. P., Vives, R. R., and Lortat-Jacob, H. (2008) J. Biol. Chem. 283, 15193-15200.

37. Shen, B., Shimmon, S., Smith, M. M., and Ghosh, P. (2003) J. Pharm. Biomed. Anal. 31, 83-93.

38. Uryu, T., Ikushima, N., Katsuraya, K., Shoji, T., Takahashi, N., Yoshida, T., Kanno, K., Murakami, T., Nakashima, H., and Yamamoto,N. (1992) Biochem. Pharmacol. 43, 2385-2392.

39. Jagodzinski, P. P., Wustner, J., Kmieciak, D., Wasik, T. J., Fertala, A., Sieron, A. L., Takahashi, M., Tsiji, T., Mimura, T., Fung, M. S., Gorny, M. K., Kloczewiak, M., Kaneko Y., and Koznor, D. (1996) Virology 226, 217-227.

40. Jeon, K., Katsuraya, K., Kaneko, Y., Mimura, T., and Uryu, T. (1997) Macromolecules 30, 1997-2001.

41. Jeon, K. J., Katsuraya, K., Inazawa, K., Kaneko, Y., Mimura, T., and Uryu. T. (2000) J. Am. Chem. Soc. 122, $12536-12541$.

42. Ishimura, T. and Yoshida, T. (2011) Polym. Prep. Jpn. 60, 4851-4852.

43. Bai, Y., Ishimura, T., and Yoshida, T. (2011) Polym. Prep. Jpn. 60, 4971.



